International Journal of Current Advanced Research

ISSN: O: 2319-6475, ISSN: P: 2319 - 6505, Impact Factor: SJIF: 5.995

Available Online at www.journalijcar.org

Volume 6; Issue 4; April 2017; Page No. 3251-3253

DOI: http://dx.doi.org/10.24327/ijcar.2017.3253.0237

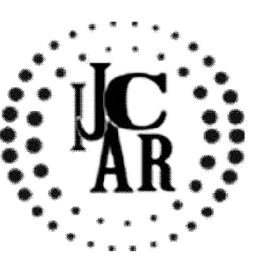

Research Article

\title{
ANTI BACTERIAL EFFECT OF ETHANOLIC LEAF EXTRACT OF CARALLUMA FIMBRIATAON E.FAECALIS -AN INVITRO STUDY
}

\author{
Jennifer Suhasini. $S^{1}$ and Anitha Roy ${ }^{2 *}$ \\ ${ }^{1}$ Bachelor of Dental Surgery, \\ 2Pharmacology, Saveetha Dental College and Hospitals, Chennai, India
}

\section{A R T I C L E I N F O}

\section{Article History:}

Received $11^{\text {th }}$ January, 2017

Received in revised form $19^{\text {th }}$ February, 2017

Accepted $22^{\text {nd }}$ March, 2017

Published online $28^{\text {th }}$ April, 2017

Key words:

Caralluma fimbriata, E.faecalis, antibacterial activity, root canal failure

\begin{abstract}
A B S T T R A C T
Aim: To evaluate the antibacterial activity of the Ethanolicleaf Extract of Caralluma fimbriata against $E$.faecalis

Method: Agar well diffusion assay as well as micro broth dilution assays were used for determination of antibacterial activity.

Results: Different concentrations of the extract $(200 \mathrm{mg} / \mathrm{mL}, 400 \mathrm{mg} / \mathrm{mL}$ and $800 \mathrm{mg} / \mathrm{mL}$ showed dose dependant antibacterial activity and the MBC was found to be more than 400 $\mathrm{mg} / \mathrm{mL}$

Conclusion: This study suggests that the Ethanolic extract of Caralluma fimbriata leafcontains promising antibacterial substances which is having activity against E.faecalis.
\end{abstract}

Copyright $₫ 2017$ Jennifer Suhasini.S and Anitha Roy. This is an open access article distributed under the Creative Commons Attribution License, which permits unrestricted use, distribution, and reproduction in any medium, provided the original work is properly cited.

\section{INTRODUCTION}

Caralluma fimbriata is a succulent plant in the family Apocynaceae. Caralluma fimbriata has been eaten in rural India for centuries, as a raw vegetable with spices, or preserved in chutneys and pickles and is often found as a roadside shrub or boundary marker.[1]Caralluma fimbriata contains pregnane glycosides, a phytochemical that blocks the enzyme citrate lyase. When this enzyme's activity is stopped, the body cannot produce fat. So, Caralluma Fimbriata blocks the enzymes responsible for breaking down and producing fatty acids in the body [2]. The main photochemicals in Caralluma fimbriata are pregnane glycosides [3,4] flavone glycosides , megastigmane glycosides [5], bitter principles, saponins, various flavonoids [6] The plant has high antioxidant[7] Anti-Inflammatory[8,9] Anti-nociceptive[10,11], anti-diabetic[12,13], anti-ulcer[14], gastric mucosa protecting,and cytoprotective properties[14]. SoCaralluma has medicinal uses in the treatment of Rheumatism, Diabetes, Leprosy, Antiseptics \& Disinfectants[15]. Caralluma fimbriata has antibacterial activity against E.coli, Bacillus SP., Proteus Sp., S. aureus, S. epidermidis, Klebsiella $S p$. So in this study, the antibacterial activity of Caralluma fimbriatais found against E.faecalis Enterococcus faecalis-is a Gram-positive, commensal bacterium inhabiting the gastrointestinal tracts of humans and other mammals.[16]

*Corresponding author: Jennifer Suhasini.S

Bachelor of Dental Surgery, cause life-threatening infections in human, especially in the nosocomial (hospital) environment, where the naturally high levels of antibiotic resistance found in E. faecaliscontribute to its pathogenicity.[16] E. faecalis has been frequently found in root canal-treated teeth in prevalence values ranging from $30 \%$ to $90 \%$ of the cases.[17]Root canal-treated teeth are about nine times more likely to harbor E.faecalis than cases of primary infections.[18]

\section{MATERIALS AND METHODS}

Materials and Methods: Ethanolic extract of extract ofCaralluma fimbriata

Microbial strain used: E. faecalis ATCC

Culture media: Mueller Hinton Agar

\section{Standardization of Bacterial Suspension}

The bacterial suspension was standardized following the CLSI guidelinesand was grown in Mueller Hinton Broth (MHB, Hi-Media) for 18-24 $\mathrm{h}$, followed by the matching of bacterial suspension to the turbidity equivalent to 0.5 McFarland solution $(1-2 \times 108 \mathrm{CFU} / \mathrm{mL})$ with the addition of sterile saline.

\section{Agar well diffusion assay}

Evaluation of the antimicrobial activity of the Ethanolic extract of Caralluma fimbriata leafextract was conducted by agar well diffusion assay method. ${ }^{[19,20]}$ The different concentrations $(200 \mathrm{mg} / \mathrm{mL}, 400, \mathrm{mg} / \mathrm{mL}$ and $800 \mathrm{mg} / \mathrm{mL})$ of the plant extract was prepared and from this $100 \mu \mathrm{L}$ was used 
for the study. $0.2 \%$ chlorhexidine was used as the control. The study was carried out in triplicate.

Minimum Inhibitory Concentration (MIC) and Minimum Bactericidal Concentration (MBC):

The MIC of the ethanolic extract of Caralluma fimbriata was determined by microbroth dilution method using 96-well microtitre plates. The MIC value of the extract was determined as the lowest concentration of the extract that completely inhibited bacterial growth after $48 \mathrm{hrs}$ of incubation at $37^{\circ} \mathrm{C} .^{[21]}$ For the determination of $\mathrm{MBC}$, a portion of liquid $(5 \mu \mathrm{l})$ from each well that exhibited no growth were taken and then sub-cultured and incubated $37 \mathrm{oC}$ for $24 \mathrm{hrs}$. The lowest concentration that revealed no visible bacterial growth after sub-culturing was taken as MBC. ${ }^{[22]}$

\section{RESULT AND DISCUSSION}

Plants have been used for thousands of years to flavor and conserve food, to treat health disorders and to prevent diseases including epidemics. The knowledge of their healing properties has been transmitted over the centuries within and among human communities[23].

In this study, different concentrations of the Ethanolic extract of Caralluma fimbriata showed maximum zone inhibition in a dose dependant manner(table :1). Maximum zone of inhibition was found to be $25 \mathrm{~mm}$ at $800 \mathrm{mg} / \mathrm{mL}$ (Fig 1). The MIC/ MBC were found to be more than $400 \mathrm{mg} / \mathrm{mL}$.Lin and Tang [24] reported that phenolic and flavonoids contents in various fruits and vegetables help immune-modulator organs, killing the microorganisms.

Table 1 Showing the zone of inhibition of the extract

\begin{tabular}{ccc}
\hline Extract & $\begin{array}{c}\text { Concentration } \\
(\mathbf{m g} / \mathbf{m L})\end{array}$ & $\begin{array}{c}\text { Zone of } \\
\text { inhibition(mm) }\end{array}$ \\
\hline Ethanolic extract & 200 & 7 \\
& 400 & 14 \\
Chlorhexidine & 800 & 25 \\
\hline
\end{tabular}

\section{Anti bacterial effect of the Ethanolic extract}

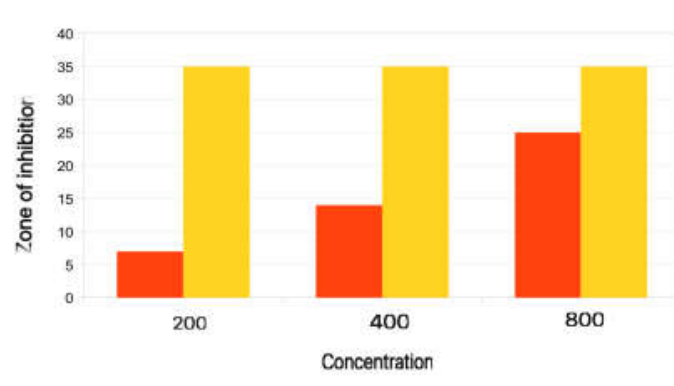

Figure 1 Graph showing anti bacterial activity of the leaf extract of Caralluma fimbriata leaf against E.faecalis

\section{CONCLUSION}

This study suggests that the Ethanolic extract of Caralluma fimbriataleaf contains promising antibacterial substances which is having activity against E.faecalis and may be considered for clinical purpose for management of E.faecalis infections.

\section{Acknowledgement}

The authors are grateful to Mr. R Rajendran, Green Chem
Herbal Extracts \& Formulations, Bangalore for providing the herbal extracts as a gift sample for the study.

and Department of microbiology, Saveetha Dental College and Hospitals for carrying out this small project .

\section{References}

1. Weighing the Evidence in Diet Ads, US Federal Trade Commission. IJPBS |Volume 3| Issue 1 |JAN-MAR |2013|281-286

2. Report on the Safety of Carallumafimbriafa and its Extract Harry G. Preuss M.D., M.A.C.N.,C.N.S.

3. Hayashi K, Iida I, Nakao Yu, Nakao Yo, Kaneko K: Four pregnane glycosides, boucerosides, AI, AII, BI, and BII from boucerosia aucheriana. Phytochemistry 27:3919-3924, 1988.

4. Abdel-Sattar E, Meselhy MR, Al-Yahya MAA: New oxypregnane glycosides from Caralluma penicillata. Planta Med 68:430-434, 2002.

5. Bader A, Braca A, De Tommasi N, Morelli I: Further constituents from Caralluma negevensis. Phytochemistry 62: 1277- 128 1,2003

6. KamilM, Fjayaraj A, Ahmad F, Gunasekhar C, Samuel $\mathrm{S}$, Chan $\mathrm{K}$, Habibullah $\mathrm{M}$ : Identification and quantification of flavonoids from Carahma arabica and its quality control studies. J Pharm Pharmacol 5 $l$ (Suppl):225, 1999.

7. Gryglewski RJ, Korbut R, Robak J. On the mechanism of antithrombotic action of flavonoids. Biochemical Pharmacol. 1987; 36: 317- 321.

8. Zakaria MNM, Islam MW, Radhakrishnan RR, Chen HB, Ismail A, Chan K, Habibullah M: Evaluation of antinociceptive and anti-inflammatory properties of Caralhma arabica. J Pharm Pharmacol 51 (Supp1)117, 1999.

9. Zakaria MNM, Islam MW, Radhakrishnan R, Chen HB, Kamil M, Al-Gifri AN, Chan K, Al-At\& A: Antinociceptive and anti-inflammatory properties of Carahma arabica. J Ethnopharm 76:155-158.2001.

10. Ramesh M, Rao YN, Rao AV, Prabhakar MC, Rao CS, Muralidhar N, Reddy BM.Antinociceptive and antiinflammatory properties of a flavonoid isolated from Caralluma attenuata. J.Ethnopharmacol. 1998; 62:6366.

11. Zakaria M.N.M, Isran M.W, Radhakrishnan R.et al, Anti-nociceptive and anti-inflammatory properties of Caralluma arebica. J.Ethanopharmacol. 2001; 76:155158.

12. VenkateshS, Reddy G.D, Reddy B.M, Ramesh M Rao A.V. Anti-hyperglycemic activity of Caralluma attenuata. Fitoterapia 2003; 74(3):274-279.

13. Wadood,A.,Wadood,N.,Wahid Shah,S.A.,Effects of Acacia arabica and Caralluma edulis on blood glucose levels of normal and diabetic rabbits J.Pak Med Assoc. 1989;39:208-212.

14. ZakariaM.N.M.,Isran M.W., Radhakrishnan R. et al., Anti-gastric ulcer and cytoprotective properties of Caralluma arabica, Pharm Biol 2002;40:225-230.

15. Neuwinger HD. African Ethnobotany. Poisons and Drugs. New York: Chapman \& Hall, 1994. p. 238239.

16. Ryan KJ, Ray CG (editors) (2004). Sherris Medical Microbiology (4th ed.). McGraw Hill. pp. 294-5. ISBN 0-8385-8529-9. 
17. Molander, A.; Reit, C.; Dahlén, G.; Kvist, T. (1998). "Microbiological status of root-filled teeth with apical periodontitis". International Endodontic Journal 31(1): 1-7. doi:10.1046/j.1365-2591.1998.t01-1-00111.x.

18. Rocas, I.; Siqueira, J.; Santos, K. (2004). "Association of Enterococcus faecalis With Different Forms of Periradicular Diseases". Journal of Endodontics 30 (5): 315-320. doi:10.1097/00004770-200405000-00004.

19. Pottumarthy, S., Fritsche, T.R. and Jone, R.N. Activity of gemifloxacin tested against Neisseria gonorrheae isolates including antimicrobial-resistant phenotypes. Digno. Microbiol. Infect. Dis., 2006, 54, 127-134.

20. Bishnu P. Marasini, Pankaj Baral, Pratibha Aryal, Kashi R. Ghimire, Sanjiv Neupane, Nabaraj Dahal, Anjana Singh, Laxman Ghimire, and Kanti Shrestha, Evaluation of Antibacterial Activity of Some Traditionally Used Medicinal Plants against Human Pathogenic Bacteria, BioMed Research International, 2015, 1 - 6 pages)
21. Chang-Geun Kang, Dae-Sik Hah, Chung-Hui Kim, Young-Hwan Kim, Euikyung Kim, and Jong-Shu Kim, Evaluation of Antimicrobial Activity of the Methanol Extracts from 8 Traditional Medicinal Plants, Toxicol Res. 2011., 27(1): 31-36.

22. Anitha Roy, Geetha R.V, Lakshmi T, Evaluation of The Anti bacterial activity of the Ethanolic Extract of Dioscorea villosa Tubers- An In Vitro study, Int $J$ Pharm Pharm Sci, 2012, 4(1), 314-316.

23. Biological properties of medicinal plants: a review of their antimicrobial activity Silva NCC (1), Fernandes Júnior A (1) The Journal of Venomous Animals and Toxins including Tropical Diseases ISSN 1678-9199| 2010|volume16|issue 3|pages 402413

\section{How to cite this article:}

Jennifer Suhasini.S and Anitha Roy (2017) ' Anti Bacterial Effect Of Ethanolic Leaf Extract Of Caralluma Fimbriataon E.Faecalis An Invitro Study', International Journal of Current Advanced Research, 06(04), pp. 3251-3253.

DOI: http://dx.doi.org/10.24327/ijcar.2017.3253.0237 